\title{
Epidemiological Investigation in Diphtheria Control in Banda Aceh, Indonesia
}

\author{
Zahratul Aini',2), Eti Poncorini Pamungkasari3), Ari Natalia Probandari3) \\ 1)Masters Program in Family Medicine, Universitas Sebelas Maret \\ ${ }^{2)}$ Department of Family Medicine, Faculty of Medicine, \\ Universitas Syiah Kuala, Banda Aceh, Indonesia \\ 3)Faculty of Medicine, Universitas Sebelas Maret
}

\section{ABSTRACT}

Background: Extraordinary events (KLB) diphtheria are still found in the city of Banda Aceh. An action is needed to break the chain of diphtheria cases and reduce the number of diphtheria morbidity or mortality, one of which is by conducting an epidemiological investiga-tion of diphtheria. This study aims to see how the implementation of diphtheria epidemiology investigations in the city of Banda Aceh and how it relates to the presence of diphtheria cases in the city of Banda Aceh.

Subjects and Method: This was a qualitative multiplecase study. Data were collected by conducting interviews with doctors in five sample community health center in Banda Aceh City. Community health centers were selected by purposive sampling based on primary data regarding the distribution of diphtheria during 2017 and 2018 in Banda Aceh City. This study combined source tri-angulation. The source triangulation informant is surveillance who served in the Banda Aceh City Health Service.

Results: The epidemiological investigation effort at the puskesmas began by immediately sending a diphtheria fast-moving team to carry out a chronological-related survey of cases and collect data on close contacts in the case environment. In close contact data collection there are community health center that do not record complete close contact so prophylaxis cannot cover all close contacts. The stage of examination of throat or nose specimens for close contact is also not carried out in some community health center.

Conclusion: Epidemiological investigations play an important role in breaking the chain of diphtheria distribution. Skipping stages in epidemiological investigations can provide a gap for the development of diphtheria in the case environment. Puskesmas that carry out a complete stage of epidemiological investigation are proven to be able to eradicate the incidence of diphtheria in their working area.

Keywords: diphtheria, surveillance, epidemiology investigation

\section{Correspondence:}

Zahratul Aini. Masters Program in Family Medicine, Universitas Sebelas Maret, Jl. Ir. Sutami 36A, Surakarta 57126, Central Java. Email: dr.zahratulaini@gmail.com. Mobile: +6281360003747 .

Cite this as:

Aini Z, Pamungkasari EP, Probandari A (2020). Epidemiological Investigation in Diphtheria Control in Banda Aceh, Indonesia. J Epidemiol Public Health. 05(02): 141-149. https://doi.org/10.26911/jepublichealth.2020.05.02.02.

(c) (i) (2) Journal of Epidemiology and Public Health is licensed under a Creative Commons EY NC SA Attribution-Non Commercial-Share Alike 4.0 International License.

\section{BACKGROUND}

Diphtheria is an acute infectious disease that is contagious. The causative agent is Corynebacterium diphteriae with the typical symptoms of pseudo membrane formed on the skin or mucosa. Diphtheria can be trans- mitted through droplets from the patient's or carrier nasopharynx (Poorwo et al., 2008; Murhekar, 2017).

Extraordinary events (KLB) diphtheria are still found in Indonesia. The incidence of diphtheria is relatively high in Aceh. In 2018, 
Aini et al./ Epidemiological investigation in diphtheria control

there were 143 reported cases of diphtheria. Banda Aceh as the capital of Aceh Province is the highest area of diphtheria patients among 13 other districts. Out of 143 cases in 2018, 24 cases occurred in Banda Aceh City (Afif, 2018).

An area has been said to be a diphtheria outbreak if there is a suspected diphtheria. An action is needed to break the chain of spread of diphtheria cases and reduce the number of morbidity or diphtheria mortality. The initial step that needs to be prepared is to form a diphtheria fast-moving team consisting of doctors, surveillance, laboratory personnel and other health workers who have been equipped with personal protective equipment (Anggraeni et al., 2017; Phan et al., 2018).

The team is engaged in tackling the diphtheria event so as not to become more widespread by carrying out epidemiological investigation procedures. Epidemiological investigations are activities consisting of chronological data collection related to the incidence of diphtheria cases, data collection of close contacts and careers, examination of specimens on suspects and close contacts to prophylaxis for close contacts (Ministry of Health Republic of Indonesia, 2013).

This study aims to examine the implementation of diphtheria epidemiology invest-

Table 1. Characteristics of the sample

\begin{tabular}{lcc}
\hline Puskesmas Name & $\begin{array}{c}\text { Number of positive diphtheria } \\
\text { cases in 2017 }\end{array}$ & $\begin{array}{c}\text { Number of positive diphtheria } \\
\text { cases in 2018 }\end{array}$ \\
\hline Puskesmas A & 1 case & No case \\
Puskesmas B & 4 cases & 3 cases \\
Puskesmas C & 3 cases & No case \\
Puskesmas D & 1 case & No case \\
Puskesmas E & 2 cases & No case \\
\hline
\end{tabular}

The researcher interviewed the doctor as part of the diphtheria rapid response team as well as the team in charge. From the interviews it was obtained that the epidemiological investigation in each sample puskesmas was carried out in coordination with the Banda tigations in Banda Aceh, Indonesia.

\section{SUBJECTS AND METHOD 1. Study Design}

This was a qualitative multiple case study. The study was conducted in the city of Banda Aceh, from June to October, 2018.

\section{Population dan Sample}

Sample health centers were selected by purposive sampling based on primary data regarding the distribution of diphtheria during 2017 and 2018 in Banda Aceh City. The sample health center is then given a code with $\mathrm{A}$, B, C, D and E.

\section{Data collection}

The data were collected by in-depth interviews in doctors at the community health centers.

\section{RESULTS}

\section{A. Sample Characteristics}

The community health center (Puskesmas) that became the study sample were those that had faced diphtheria cases in their working areas in 2017 and 2018. Endimicity data of diphtheria distribution in each community health center were obtained from the Banda Aceh Health Office. Of the eleven community health centers in Banda Aceh City, five community health center were taken as samples. The following are sample characteristics.
Aceh city health office, as revealed by the community health center doctor E:

"At that time (when there was a case in 2017) (an epidemiological investigation) was carried out, still in coordination with the health department, because this was 
Aini et al./ Epidemiological investigation in diphtheria control

no joke, one case was considered an outbreak."

Epidemiological investigation procedures begin by gathering information about the patient's personal data suspected of diphtheria (suspected). Diphtheria fast-moving team in this case surveillance, will go to the address of suspected diphtheria to collect all information regarding the chronology of diphtheria events. However, surveillance often encounters obstacles, namely the invalid patient data and many patients' families who are not cooperative in providing information to the surveillance, even there is resistance from the community. They assume that diphtheria is a frightening disease. Families of patients are afraid of being ostracized, if their personal data is submitted to the officers. This was revealed by a triangulation informant at the Banda Aceh City Health Office:

"We field people are not as easy as people who sit behind a desk, I say (say) frankly (frankly), (that) my children (subordinate informants) who are in the puskesmas or in this office there are also surveillance (already) pretty much met obstacles. As they descend it (carry out epidemiological investigations) (constraints) the first (is) address. The address (given) often (times) they (patients) only (say) the name of the village, then we have to find out more (in full). Then acceptance from the community itself, acceptance from families affected by the case, so things like that that we might need to be more heartened. For my own officers, that is our obstacle in the field, the first is the rejection from his family then the unclear address made in the status itself, so it makes my officers have to go back and forth, that is the obstacle I have been getting up to now ".

Epidemiological investigations not only collect information about patient personal data but also record the possibility of close contact and careers in the patient's envi- ronment. $\mathrm{E}$ has been done in full. The close contact recorded is not only limited to family members who live at home with diphtheria suspected patients but also includes the possibility of other close contacts such as neighbors, playmates, school friends and teachers around the suspect environment. The diphtheria fast-moving team at community health center $\mathrm{A}, \mathrm{C}, \mathrm{D}$ and $\mathrm{E}$ has also monitored the possibility of careers between close contacts. The team conducted an epidemiological investigation continuously for eleven days by observing family and neighbors in the area near the patient's residence. If there are complaints of diphtheria-like illness such as coughing, runny nose and difficulty swallowing on close contact observation, the doctor will conduct further physical examination to confirm the diagnosis of close contact with diphtheria or not.

As stated in the following interview excerpt from the doctor of community health center A:

"We have done (prophylaxis), so we usually give erythromycin to the suspect, then the family around (in the same house), close contact and career". Data collection of close contacts is not yet complete in community health center $\mathrm{B}$. The main informant at community health center B said that if there were diphtheria cases, health workers immediately conducted a survey to collect data and provide education to suspected diphtheria homes. Community health center B diphtheria management team only did a close contact data collection at the patient's home. No data collection was made on other possible close contacts in the patient's environment. The same is true of career data collection. This is evidenced by the epidemiological investigation report of community health center B that researchers got from the triangulation of data. The following is an interview with the doctor from Puskesmas B: 
Aini et al./ Epidemiological investigation in diphtheria control

"Even if there are cases that we encounter in the field, there are those suspected of diphtheria cases, we directly (carry out) a survey to the home (patient), see the condition of the patient, we do (education in the form of) an explanation. We educate the patient so that he can understand what diphtheria is. So even though there is one family (found only) one person affected by diphtheria (te) but (other members of) other families must also be given prophylactic drugs to prevent diphtheria".

The next set of diphtheria treatment in epidemiological investigations is the examination of nasal or throat specimens. The examination of diphtheria specimens is not only done in patients suspected of diphtheria, but also must be carried out on close contact. Based on observational data that researchers collected, the stages of examining specimens in close contact were missed by almost all sample health centers. They only asked for specimen examination in diphtheria patients. According to the information from the main informant at Puskesmas E, the limitations of laboratory experts in Banda Aceh City were an obstacle for puskesmas to examine specimens for close contact. Health centers in Banda Aceh City do not have trained laboratory staff to carry out specimens for suspected diphtheria sufferers. Banda Aceh only has one competent laboratory officer and works in the Banda Aceh City regional health laboratory.

The doctor in puskesmas E stated:

"There is no training on how to collect specimens for laboratory assistants, there are no reagents, so everything is submitted to the service".

Community health center $\mathrm{C}$ is the only community health center that has examined specimens in close contact in 2017 when diphtheria occurred in the community health cen- ter $\mathrm{C}$ working area. These data are obtained from observations and interviews with doctors and surveillance at puskesmas $\mathrm{C}$, the fast-moving team prevention of diphtheria has carried out epidemiological investigations by recording all close contacts and also randomly examining the throat smears on close contact. The throat swab was taken by trained laboratory staff in collaboration with the Banda Aceh City Health Office.

The next stage in epidemiological investigation is prophylaxis for close contact and possible careers. In interviews with the five main informants in all sample health centers, it was discovered that before giving prophylaxis in the form of erythromycin for close contact, the officer first provided education to the families of suspected diphtheria patients about the risk of diphtheria transmission to family members. The official explained the importance of prophylaxis as a preventative drug, the procedure for taking prophylaxis and how it has side effects. All close contacts were given erythromycin antibiotics at a dose of $4 \times 500 \mathrm{mg}$ for seven days. Doctors also gave antacids to suppress the side effects of erythromycin. The following is an excerpt from an interview with the doctor from community health center B regarding diphtheria prophylkasis:

"So like yesterday's case, there are cases that we suspect that family members already suffer from diphtheria, we immediately explain to family members at home, their mothers and fathers as well, we explain that if a family member has been infected with diphtheria, we suspect transmission can occur. family members in the house immediately we give antibiotics erythromycin $4 \times 500 \mathrm{mg}$ for seven days and we also explain the side effects of erythromycin which can increase gastric acid, so to anticipate we immediately give antacid drugs, to anticipate the side effects of the drug ery- 
Aini et al./ Epidemiological investigation in diphtheria control

thromycin. We give it to children in the form of syrup in accordance with the child's weight dose and we also give it for seven days".

The close contact recorded in the epidemiological investigation at Puskesmas B is limited to family members who live in one house with the patient, so prophylaxis does not cover all close contact or suspected careers.

\section{DISCUSSION}

Epidemiological investigations are activities carried out in a planned manner to investigate health cases that occur in a work area. Investigation is related to how chronologically the case occurs, confirms the diagnosis, looks for additional cases, and makes sure there is an outbreak. In the case of diphtheria, epidemiological investigations aim to determine the risk factors for diphtheria so that the spread of diphtheria can be stopped immediately (Widoyono, 2008; Ramdan et al., 2018).

Previous studies examining diphtheria epidemiological investigations have been carried out in Ngawi district by Rahman et al. (2015), it was stated that the officers in general had carried out epidemiological investigative procedures when an outbreak occurred. Activities carried out began to visit the sufferer's home, school and playground to survey close contact. Then this close contact is observed for several days, the aim is if anyone who shows symptoms similar to diphtheria is immediately treated further. Coordination with the Provincial Health Office is carried out, where reports must be submitted within one day of the case finding (Rahman and Hargono, 2016).

Based on the stages of the procedure prepared by the Ministry of Health of the Republic of Indonesia, diphtheria events must be reported in less than 24 hours since the case was discovered (Anggraeni et al., 2017). If the case is found in the community health center work area, the surveillance officer coordinates with the community health center doctor to confirm the diagnosis of the patient. After being diagnosed with diphtheria, it is immediately referred to a hospital with available isolation facilities to treat diphtheria patients. However, if a patient diagnosed with diphtheria is found in a hospital, the health office will contact the community health center surveillance according to the patient's domicile to immediately conduct an epidemiological investigation. In this case surveillance first ascertain whether the patient is a true citizen and where the patient contracted diphtheria for the first time.

The next stage, surveillance conducts epidemiological investigations and writes detailed reports on the available W1 (Outbreak 1) sheet. This epidemiological investigation report must be under the supervision of a doctor as the head of the community health center. The mechanism for making this epidemiological report was explained by a triangulation informant in the Banda Aceh City Health Office in the following interview:

"As long as there are cases, after we brief the surveillance officer, the report remains (originated) from the surveillance. There is a term $W 1$ report, a report that (must be reported in) 24 hours (after it was found) that outbreak in W1 (is) a surveillance task that will report. The surveillance officer, when he gets a case, he (surveillance) coordinates with his doctor, (then) the doctor carries out an examination, that is if it is found (a case) at the community health center. But if it is found in a hospital, the official who informs, in the area of the community health center there is a case, then the surveillance officer (from the community health center) will conduct an epidemiological investigation, he ascertain whether (the case) did (occur) in his first area, the second is how to investigate immunizations there, 
Aini et al./ Epidemiological investigation in diphtheria control

then where can this be the case.

So, this surveillance person must know, the report (from), from $\mathrm{W} 1$ is immediately known. The chronology is made from the officer for the first stage, when he (surveillance) (men) gets information, then when an epidemiological investigation is conducted, (anything) what he finds in the field, and what actions have been taken. If (the case) is found at the community health center, then he (surveillance) already knows (the patient) entered (diagnosed early) from the poly (community health center), what (only) has been given by the doctor (community health center), but if the patient has been treated at the hospital, he must know in which room to be treated, then what is the implementation (therapy) carried out by doctors at the hospital. W1 report must be known by the head of the community health center ".

Prevention of the spread of diphtheria is not only in diphtheria patients but also includes people in the vicinity of diphtheria patients who are called close contacts. Close contact is considered as a person who is very at risk of contracting diphtheria bacteria. Close contact must be monitored for seven days from the last contact with the case to rule out suspected close contact into a career. The procedure for close contact is almost the same as in diphtheria patients, but close contact does not need to be isolated. The procedure for close contact includes, giving erythromycin as a prophylactic drug 4 x $500 \mathrm{mg}$ for seven to ten days, diphtheria basic immunization is given to close contacts that have not been immunized, whereas for close contacts who have been immunized are given a booster dose immunization if the last immunization has been more than five years, and the final stage is examining throat or nasal smear specimens (Phalkey et al., 2013; Washington State Department of Health, 2016).

Provision of prophylaxis to all close contacts serves as an effort to break the chain of diphtheria transmission. Surveillance of sample community health center has recorded close contact first and then prophylaxis. Data collection of close contacts that only revolves around families living together with patients in cases in community health center $B$ causes not all close contacts that infectious to get prophylaxis. Epidemiological investigations play an important role in the prevention of diphtheria, so that if you miss just one procedure in an epidemiological investigation it will have an effect at a later stage. As was the case with community health center B, the collection of close contacts and prophylaxis which did not include all close contacts could have been the cause of the diphtheria cases at community health center B until October 2018.

Provision of prophylaxis also includes a career. Careers are people who do not have signs and symptoms of diphtheria but on laboratory tests have been proven to be infected with the bacteria C. Diphtheria. For that we need to find career risks between close contact. Career management is by giving anti-microbial form of penicillin $100 \mathrm{mg} / \mathrm{Kg}$ $\mathrm{BW} /$ day orally or intravenously or by giving erythromycin $40 \mathrm{mg} / \mathrm{Kg} \mathrm{BW} /$ day for seven days (Haryato, 2018).

The next stage in epidemiological investigations is the examination of specimens in close contact. All close contacts around patients diagnosed with diphtheria take throat or nasal specimens without looking at previous immunization status and the presence or absence of diphtheria-like symptoms (Fitriana and Novriani, 2014).

This is done to ascertain whether positive or negative close contact is infected with diphtheria bacteria. This procedure determines the time period of erythromycin administration, which is seven days if it is proven to be negative for $\mathrm{C}$. Diphtheria bacteria or continued for fourteen days if it is 
Aini et al./ Epidemiological investigation in diphtheria control

proven to be positive for C. Diphtheria bacteria (Ministry of Health, Republic of Indonesia, 2013).

The city of Banda Aceh is constrained by the lack of trained laboratory staff for taking diphtheria specimens and the unavailability of laboratory facilities for microbiological examination (Aini and Poncorini, 2019).

As a result of not examining specimens in close contact is the difficulty of detecting possible careers from close contact and cannot be a reference in administering close contact prophylaxis. Close contact that has been proven positive for diphtheria from laboratory tests should be treated differently from close contact with the negative bacteria C. Diphtheria (Irawan, 2014).

Epidemiological investigations as a form of prevention of diphtheria outbreaks in the city of Banda Aceh generally have tried to be carried out optimally in every community health center. community health center that carry out a complete stage of epidemiological investigation are proven to be able to eradicate the incidence of diphtheria in their working area. Skipping the stages of the epidemiological investigation procedure can provide a gap for the development of diphtheria germs in the case environment. Incomplete close contact data collection at community health center $B$ results in prophylaxis that cannot cover all close contacts. Close contact is a person who is very susceptible to diphtheria. If close contact is not handled entirely, the chain of diphtheria transmission cannot be broken (Irawan, 2014; Jané et al., 2018).

Supervision of team performance is required, not only relying on the implementation of epidemiological investigations to field officers such as surveillance, but doctors are also required to be able to supervise the stages of conducting epidemiological investigations so that no more stages are missed to break the chain of diphtheria distribution. Related parties such as the health department are also expected to make observations on epidemiological investigations at each community health center.

The role of the doctor as the person in charge of the diphtheria rapid motion team is needed to oversee the epidemiological investigation procedures. Doctors are expected to play an active role, not just hand over all the conduct of epidemiological investigations to field officers. Incomplete data collection in epidemiological investigations such as in community health center B, proves the lack of doctor supervision on the performance of officers. In this study the researchers only interviewed doctors as the person in charge of the diphtheria fast-moving team but did not interview the other team members so it is unknown why some officers did not carry out epidemiological investigation procedures as determined by the Ministry of Health of the Republic of Indonesia.

\section{AUTHOR CONTRIBUTION}

Zahratul Aini, Eti Poncorini Pamungkasari, and Ari Natalia Probandari collected the data and wrote the paper.

\section{CONFLICT OF INTEREST}

There is no conflict of interest in this study.

FUNDING AND SPONSORSHIP This study is self-funded.

\section{ACKNOWLEDGEMENT}

The researcher would like to thank all the informants, namely doctors from the community health center in Banda Aceh City and the Banda Aceh City Health Office.

\section{REFERENCE}

Afif (2018). Aceh Jadi Provinsi Ketiga di Indonesia Pengidap Difteri Terbanyak (Aceh Becomes the Third Province in Indonesia with the Most Diphtheria). 
Aini et al./ Epidemiological investigation in diphtheria control

Retrieved from: https://www.merde$\mathrm{ka} . c o m /$ peristiwa/aceh-jadi-provinsiketiga-di-indonesia-pengidap-difteriterbanyak.html

Aini Z, Poncorini E, Probandari AN (2019). Optimization of surveilance and laboratory technicians in diphtheria outbreak control in Banda Aceh, Aceh. International conference on Public health. https://doi.org/10.26911/theicph.2019. 01.27.

Anggraeni ND, Yosephine P, Natalia U, Mazanova D, Handini S, Widodo N, Anom IB, et al (2017). Pedoman Pencegahan dan Pengendalian Difteri (Guidelines for Prevention and Control of Diphtheria). Jakarta: Kementerian Kesehatan Republik Indonesia

Fitriana, Novriani H (2014). Penatalaksanaan Difteri (Management of Diphtheria). Jurnal Indon Med Assoc, 64(12): 541-545

Haryato E (2018). Difteri Pada Anak (Diphtheria in Children). Sari Pediatri. 19(5): 300-306

Irawan H (2014). Diphteria: Re-Emerging Disease Dalam Current Evidences In Pediatric Emergencies Management. Jakarta: Departemen Ilmu Kesehatan Anak FKUI/RSCM

Jané M,Vidal MJ, Camps N, Campins M, Martínez A, Balcells J, Martin-Gomez MT, et al. (2018). A case of respiratory toxigenic diphtheria: contact tracing results and considerations following a 30-year disease-free interval, Catalonia, Spain, 2015. Euro Surveill. 23(13): pii= 17-00183. https://doi.org/10.2807/1560-7917.ES.2018.23.13.17-00183

Ministry of Health RI (2013). Petunjuk teknis pelaksanaan imunisasi dan surveilans dalam rangka penganggulangan kejadian luar biasa (KLB) Difteri (Technical Guidelines for the Implementation of Immunization and Surveillance in the
Context of Overcoming Diphtheria Extraordinary Events (KLB)). Jakarta: Direktorat Jendral Pengendalian Penyakit dan Penyehatan Lingkungan Kementerian Kesehatan Republik Indonesia

Murhekar M (2017). Epidemiology of Diphtheria in India, 1996-2016: Implications for Prevention and Control. The American Journal of Tropical Medicine and Hygiene. 97(2): $313-318$. https://doi.org/10.4269/ajtmh.17-0047

Phalkey RK, Bhosale RV, Joshi AP, Wakchoure SS, Tambe MP, Awate P, Marx M (2013). Preventing the preventable through effective surveillance: the case of diphtheria in a rural district of Maharashtra, India. BMC Public Health. 13: 317. https://dx.doi.org/10.1186\%2F1471-2458-13-317

Phan LT, Pham Q, Phan HC, Nguyen TV, Phan TV, Luong QC, Vo DTT, et al.. (2018). An investigation of an outbreak of diphtheria in adolescents and adults in southern Vietnam. Int J Infect Dis. 73(90): 3-398. https://doi.org/10.1016/j.ijid.2018.04.3628.

Poorwo S, Garna H, Rezeki S, Irawan H (20o8) Infeksi dan Pediatri Tropis (Infections and Tropical Paediatrics). Kedua. Jakarta: bagian IKA Fakultas Kedokteran Universitas Indonesia

Rahman F, Hargono A, Susilastuti F (2016). Penyelidikan Epidemiologi KLB Difteri Di Kecamatan Geneng dan Karang Jati kabupaten Ngawi tahun 2015 (Epidemiological investigation of diphtheria outbreaks in Geneng and Karang Jati Districts in Ngawi Regency in 2015). Jurnal Wiyata. 3(2): 199-212. http://dx.doi.org/10.20473/jbe.V6I22018.103-111.

Ramdan IM, Susanti R, Ifroh RH, Noviasty R (2018). Risk factors for diphtheria outbreak in children aged 1-10 years in East Kalimantan Province, Indonesia. 
Aini et al./ Epidemiological investigation in diphtheria control

F100oResearch. 7: 1625. https://doi.org/10.12688/f10ooresearch.16433.1 Washington State Department of Health (2016) Diphtheria Reporting and Investigation Guideline. Washington DC: Washington State Department of
Health

Widoyono (2008). Penyakit Tropis, Epidemiologi, Penularan, Pencegahan Dan Pemberantasannya (Tropical Disease, Epidemiology, Transmission, Prevention and Eradication). Jakarta: Erlangga 